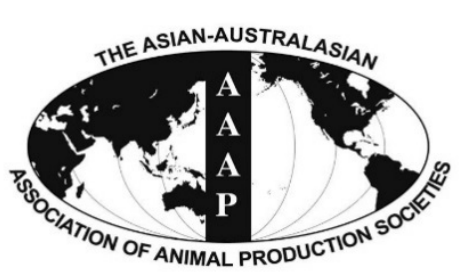

Open Access

Asian Australas. J. Anim. Sci.

Vol. 28, No. 12 : 1729-1735 December 2015

http://dx.doi.org/10.5713/ajas.15.0290

www.ajas.info

pISSN 1011-2367 elSSN 1976-5517

\title{
Effect of Medicinal Plant By-products Supplementation to Total Mixed Ration on Growth Performance, Carcass Characteristics and Economic Efficacy in the Late Fattening Period of Hanwoo Steers
}

\author{
S. J. Lee, D. H. Kim, ${ }^{1, a}$, Le Luo Guan'², S. K. Ahn, K. W. Cho³, and Sung S. Lee* \\ Division of Applied Life Science (BK21 Program), \\ Graduate School of Gyeongsang National University \& Institute of Agriculture and Life Science, Jinju 52650, Korea
}

\begin{abstract}
This study was conducted to evaluate the effect of medicinal plant by-products (MPB) supplementation to a total mixed ration (TMR) on growth, carcass characteristics and economic efficacy in the late fattening period of Hanwoo steers. Twenty seven steers (body weight [BW], $573 \pm 57 \mathrm{~kg}$ ) were assigned to 3 treatment groups so that each treatment based on BW contained 9 animals. All groups received ad libitum TMR throughout the feeding trial until slaughter (from 24 to 30 months of age) and treatments were as follows: control, $1,000 \mathrm{~g} / \mathrm{kg}$ TMR; treatment 1 (T1), $970 \mathrm{~g} / \mathrm{kg}$ TMR and $30 \mathrm{~g} / \mathrm{kg} \mathrm{MPB}$; treatment 2 (T2), $950 \mathrm{~g} / \mathrm{kg}$ TMR and $50 \mathrm{~g} / \mathrm{kg}$ MPB. Initial and final BW were not different among treatments. Resultant data were analyzed using general linear models of SAS. Average daily gain and feed efficiency were higher $(\mathrm{p}<0.05)$ for $\mathrm{T} 1$ than control, but there was no difference between control and T2. Plasma albumin showed low-, intermediate- and high-level $(\mathrm{p}<0.05)$ for control, T1 and T2, whereas non-esterified fatty acid was high-, intermediate- and high-level $(\mathrm{p}<0.05)$ for control, T1 and T2, respectively. Carcass weight, carcass rate, backfat thickness and rib eye muscle area were not affected by MPB supplementation, whereas quality and yield grades were highest $(\mathrm{p}<0.05)$ for $\mathrm{T} 1$ and $\mathrm{T} 2$, respectively. Daily feed costs were decreased by $0.5 \%$ and $0.8 \%$ and carcass prices were increased by $18.1 \%$ and $7.6 \%$ for $\mathrm{T} 1$ and $\mathrm{T} 2$ compared to control, resulting from substituting TMR with 30 and $50 \mathrm{~g} / \mathrm{kg}$ MPB, respectively. In conclusion, the substituting TMR by $30 \mathrm{~g} / \mathrm{kg}$ MPB may be a potential feed supplement approach to improve economic efficacy in the late fattening period of Hanwoo steers. (Key Words: Medicinal Plant Byproducts, Growth Performance, Carcass Characteristic, Hanwoo Steer)
\end{abstract}

\section{INTRODUCTION}

Increasing consumers' demand for herbal health products, combined with an enhanced technology in liquid extraction procedure from medicinal plants, has led to an increased production in medicinal plant by-products (MPB). It was

\footnotetext{
* Corresponding Author: Sung S. Lee. Tel: +82-55-772-1883, Fax: +82-55-772-1880, E-mail: lss@gnu.ac.kr

1 Eco-friendly Biomaterial Research Center, Korea Research Institute of Bioscience and Biotechnology, Jeongeup 56212, Korea.

2 Department of Agricultural, Food and Nutritional Science,

University of Alberta, Edmonton, Alberta, Canada.

3 Department of Veterinary Medicine, Gyeongsang National University, Jinju 52650, Korea.

${ }^{a}$ These authors made an equal contribution to this paper.

Submitted Apr. 2, 2015; Revised May 28, 2015; Accepted Jun. 11, 2015
}

estimated that more than 1.9 million tons MPB were produced per year in South Korea (Lee et al., 2006). Medicinal plants contain various substances such as antimicrobials, antiviral, and stimulants of immune system which can be beneficial for animal health. Similarly, MBP may have positive effects in animal production by providing a decrease in stress and an improvement in their health. Therefore, using MPB as additives to animal diets may be an economically feasible alternative and eco-friendly option as low cost feed additives or substitutes for feedstuffs (Choi et al., 1996; Park and Yoo, 1999) and may assist in reducing the improper disposal of MPB as environmental pollutants.

Although medicinal plants or their by-products should be used with care because elevated supplementation can stimulate undesirable side effects for animals (Vandergrift, 1998), some studies have reported an increased body gain

Copyright (c) 2015 by Asian-Australasian Journal of Animal Sciences This is an open-access article distributed under the terms of the Creative Commons Attribution Non-Commercial License (http://creativecommons.org/licenses/by-nc/3.0/), which permits unrestricted non-commercial use, distribution, and reproduction in any medium, provided the original work is properly cited. 
and improved meat quality when the effects of MPB on swine and poultry diets were evaluated (Kim et al., 2008; Park and Song, 1997). They suggested that supplementing diets with phytochemicals exhibiting antioxidant properties may produce meat products that contain antioxidant substances and thus enhance meat quality. Also, there are reports that beef color tends to improve with supplementation of antioxidant substances, resulting in reduced absorption of iron (Disler et al., 1975; Goto et al., 1996). However, no information on MPB as feed additives for ruminants is available. Therefore, this study was conducted to determine the effects of MPB supplementation to a total mixed ration (TMR) for Hanwoo steers on growth performance, blood characteristics, carcass characteristics and economic efficacy.

Table 1. Ingredient and chemical compositions of total mixed ration

\begin{tabular}{|c|c|}
\hline Item & Value $(\mathrm{g} / \mathrm{kg})$ \\
\hline \multicolumn{2}{|l|}{ Ingredients, as-fed basis } \\
\hline \multicolumn{2}{|l|}{ Concentrate } \\
\hline Corn & 223 \\
\hline Barley & 130 \\
\hline Wheat bran & 35 \\
\hline Coconut meal & 30 \\
\hline Palm meal & 24 \\
\hline Wheat ground & 18 \\
\hline Distiller dried grains & 18 \\
\hline Malt meal & 18 \\
\hline Walnut meal & 9 \\
\hline Plum meal & 6 \\
\hline Molasses & 12 \\
\hline Vitamin-mineral premix ${ }^{1}$ & 8 \\
\hline Limestone & 5 \\
\hline Salt & 2 \\
\hline Liquid probiotics ${ }^{2}$ & 220 \\
\hline Rice straw & 80 \\
\hline Italian ryegrass & 80 \\
\hline Tangerine by-product & 80 \\
\hline Cotton seed meal pellet & 5 \\
\hline \multicolumn{2}{|c|}{ Chemical composition, as-fed basis } \\
\hline Moisture & 455 \\
\hline Crude protein & 64 \\
\hline Ether extract & 19 \\
\hline Crude fiber & 121 \\
\hline Ash & 46 \\
\hline
\end{tabular}

DM, dry matter.

${ }^{1}$ Supplied per kilogram of diet: 3,800 IU vitamin A, 400 IU vitamin D, 500 IU vitamin $\mathrm{E}, 2.5 \mathrm{mg}$ vitamin $\mathrm{B}_{2}, 2.0 \mathrm{mg}$ vitamin $\mathrm{B}_{6}, 2.6 \mathrm{mg}$ niacin, 4.0 $\mathrm{mg}$ pantothenic acid, $50 \mathrm{mg} \mathrm{Fe}, 7.0 \mathrm{mg} \mathrm{Cu}, 2.4 \mathrm{mg} \mathrm{Mn}, 30 \mathrm{mg} \mathrm{Zn}, 6.0 \mathrm{mg}$ $\mathrm{I}, 1.5 \mathrm{mg} \mathrm{Se}$, and $1.5 \mathrm{mg}$ Co.

${ }^{2}$ The probiotics was used liquid cultivation type and it was contained $3.3 \times 10^{6}$ colony forming unit (cfu) $/ \mathrm{mL}$ Lactobacillus spp., $2.9 \times 10^{6} \mathrm{cfu} / \mathrm{mL}$ Rhodobacter spp. and $4.0 \times 10^{6} \mathrm{cfu} / \mathrm{mL}$ Saccharomyces cerevisiae, and contained more than $95 \%$ of moisture.

\section{MATERIALS AND METHODS}

All experimental procedures involving animals were approved by the Animal Care Committee of Gyeongsang National University.

\section{Animals, diets and management}

A feeding trial was conducted using twenty seven Hanwoo steers aged $24.0 \pm 0.3$ months with an average initial body weight (BW) of $573 \pm 57 \mathrm{~kg}$ to evaluate the effects of MPB supplementation. Steers were assigned to 3 treatments based on BW and each treatment contained 9 animals. They were housed with a free access to water and were fed a TMR (Cha-Hwang environment-friendly Livestock and Agricultural Union Corporation, San-Cheong, Korea) ad libitum for 180 days. The ingredients and composition of TMR and MPB are presented in Table 1 and 2, respectively.

The MPB were substituted for TMR in the 3 treatment groups at the following levels: control, $1,000 \mathrm{~g} / \mathrm{kg} \mathrm{TMR}$ and $0 \mathrm{~g} / \mathrm{kg}$ MPB; treatment 1 (T1), $970 \mathrm{~g} / \mathrm{kg}$ TMR and $30 \mathrm{~g} / \mathrm{kg}$ MPB; and treatment 2 (T2), $950 \mathrm{~g} / \mathrm{kg}$ TMR and $50 \mathrm{~g} / \mathrm{kg} \mathrm{MPB}$, respectively. Feed samples were dried in a forced-air oven at $130^{\circ} \mathrm{C}$ for $2 \mathrm{~h}$, ground through a 2-mm screen in a Wiley mill (Model 4, Thomas Scientific, Swedesboro, NJ, USA). The dried ground samples were analyzed for dry matter and crude protein according to the procedure of AOAC (2005). Ether extract was analyzed by the diethyl ether extraction in an Extraction System (B-811, Buchi, Flawil, Switzerland). Crude fiber was analyzed by the filtration method in Fiber Analyzer (Ankom A220, Mill tech, Seongnam, Korea), and ash was analyzed by the electric muffle furnace (KMF-500, Lab Corporation, Seoul, Korea) at $550^{\circ} \mathrm{C}$.

Table 2. Ingredient and chemical compositions of medicinal plant by-products

\begin{tabular}{llc}
\hline Item & Korean name & Value $(\mathrm{g} / \mathrm{kg})$ \\
\hline Ingredient, as-fed basis & & \\
Rehmanniae radix preparata & Sukjihwang & 118 \\
Angelica gigas nakai & Danggui & 118 \\
Zingiber officinale roscoe & Sangkang & 108 \\
Paeoniae radix & Jakyak & 108 \\
Cnidii rhizome & Cheongung & 97 \\
Zizyphus jujuba & Daechu & 97 \\
Citrus nobilis makino & Kyul & 97 \\
Bupleuri radix & Siho & 86 \\
Plantago asiatica L. & Jilkyungi & 86 \\
Prunus mume & Maesil & 86 \\
Chemical composition, DM basis & & \\
Crude protein & & 92 \\
Crude fat & & 36 \\
Crude fiber & & 39 \\
Ash & & \\
\hline DM & &
\end{tabular}

DM, dry matter. 


\section{Sampling, measurements and chemical analysis}

BW was measured at the beginning of the feeding trial for each animal followed by once every month and at the end of experiment. At the end of the feeding trial, blood samples $(10 \mathrm{~mL})$ were taken by venipuncture from the jugular veins using heparinized vacuum tubes and were stored on ice until analysis. Whole blood was subjected to analysis in an automatic hematological analyzer (VET abc, Montpellier, France) within $2 \mathrm{~h}$ after sampling. The plasma was obtained from a portion of collected whole blood by centrifugation at $2,500 \times \mathrm{g}$ for $30 \mathrm{~min}$ at $4^{\circ} \mathrm{C}$ and stored at $-20^{\circ} \mathrm{C}$ until analysis. Total protein, albumin, calcium, phosphorus, non-esterified fatty acid (NEFA), blood urea nitrogen (BUN) and corticoid were analyzed by an automatic blood analyzer (Express Plus, Bayer, Medfield, MA, USA).

At the end of feeding trial all steers were slaughtered after a $24 \mathrm{~h}$ fasting period. They were stunned, exsanguinated, and immediately eviscerated. Carcasses were chilled at between $0^{\circ} \mathrm{C}$ to $2^{\circ} \mathrm{C}$ for $24 \mathrm{~h}$. The carcasses were then graded for quality and yield factors from the longissmus dorsi taken at 13th rib. Quality and yield grading were performed by trained personnel of the Animal Products Grading Service in Seoul, South Korea. Carcass weight, back-fat thickness and size of loin-eye area were assessed. Yield grade was classified with a scale of 1,2 , or 3 , where 1 is high yield and 3 is low yield. Quality grade was scored on a scale of 1, 2, 3, 4 , and 5 , which was mainly determined by marbling score but also by meat color, fat color and maturity.

\section{Economic efficacy analysis}

The economic analysis of carcass production was calculated based on the cost of feed input and the price of carcass. The total feed cost did not include basic costs such as labor, equipment, electricity and water. The carcass price was determined based on the meat grades and carcass weight of steers.

\section{Statistical analysis}

Data for steers within each treatment were averaged and analyzed using the general linear model procedure of SAS (SAS Institute Inc., Cary, NC, USA) with steer as random effects, and treatments as fixed effects. Duncan's multiple range test was used to interpret any significant differences among the mean values of the treatments. Differences among treatment groups were considered significant if $\mathrm{p}<0.05$, whereas when $0.05<\mathrm{p} \leq 0.10$, differences were considered to indicate a trend towards significance.

\section{RESULTS AND DISCUSSION}

\section{Growth performance}

Initial and final BW were not different among treatment groups (Table 3 ). Average daily gain and feed efficiency were higher $(\mathrm{p}<0.05)$ for $\mathrm{T} 1$ than control, whereas feed intake was not different among treatments. BWs are commonly used for monitoring nutritional status and growth of animals (Ndlovu et al., 2009). In beef cattle production, total weight gain and daily gain are very important factors from an economic point of view. The higher feed efficiency for T1 might be a result of higher average daily gain and numerically lower total feed intake for T1 compared with control and T2, suggesting that $30 \mathrm{~g} / \mathrm{kg}$ MPB supplementation to TMR may improve feed efficiency in Hanwoo steers. It is supported by the fact that in appropriate quantities some herbs stimulated the appetite and digestion process of calves (Aboul-Fotouh et al., 2000; Ahmed et al., 2009; Hadiya et al., 2009), because medicinal plants have antimicrobial characteristics which could affect inappropriate microbes in the rumen. However, such an effect was not observed with elevated supplementation of MPB to TMR (T2 group) in the present study which decreased the feed efficiency. There are medicinal plants with suspected adverse effects, either alone or in combination (Elvin-Lewis, 2001). In general, the safety and effectiveness of alternative feeds for animals have not been

Table 3. Substitution effect of a total mixed ration by medicinal plant by-products on growth and feed efficiency in the late fattening period of Hanwoo steers

\begin{tabular}{|c|c|c|c|c|}
\hline \multirow{2}{*}{ Item } & \multicolumn{3}{|c|}{ Treatment $^{1}$} & \multirow{2}{*}{ SEM } \\
\hline & Control & Treatment 1 & Treatment 2 & \\
\hline No. of animals & 9 & 9 & 9 & \\
\hline \multicolumn{5}{|l|}{ Growth performance } \\
\hline Initial body weight $(\mathrm{kg})$ & 569 & 580 & 570 & 57.4 \\
\hline Finished body weight $(\mathrm{kg})$ & 653 & 682 & 655 & 52.0 \\
\hline Average daily gain (kg/d) & $0.469^{y}$ & $0.560^{\mathrm{x}}$ & $0.470^{y}$ & 0.05 \\
\hline \multicolumn{5}{|l|}{ Feed intake $(\mathrm{kg} / \mathrm{d})$} \\
\hline Total feed intake & 9.23 & 8.71 & 9.14 & 0.50 \\
\hline Feed efficiency (kg/kg) & $0.051^{y}$ & $0.089^{x}$ & $0.051^{\mathrm{y}}$ & 0.001 \\
\hline
\end{tabular}

SEM, standard error of the means.

${ }^{1}$ Medicinal plant by-products supplied to total mixed ration: control, no supplement; treatment $1,30 \mathrm{~g} / \mathrm{kg}$; treatment $2,50 \mathrm{~g} / \mathrm{kg}$.

${ }^{\mathrm{x}, \mathrm{y}}$ Values in the same row with different superscripts differ at $\mathrm{p}<0.05$. 
fully proven and remain largely unknown. Therefore, they should be used with care because elevated supplementation of some medicinal plants may stimulate undesirable side effects (Vandergrift, 1998) which warrants further investigations on health aspects of MPB as feed additives.

\section{Blood characteristics}

White blood cells, which play a major role in defending the body against disease-producing bacteria, viruses and fungi, binds to infectious agents and helps in preventing them from damaging the body. Therefore, a deficiency of white blood cells may result in an increased susceptibility to infections. Although no statistically difference was observed among treatments ( $p>0.05$, Table 4), numerically increased white blood cell counts with MPB supplementation may indicate an improved sign of immunity.

No significant differences were observed for red blood cell and platelets among treatments, whereas hemoglobin and hematocrit were higher $(\mathrm{p}<0.05)$ for $\mathrm{T} 1$ and T2 than control group (Table 4). A shortage of red cells produces a condition of anemia, which can cause weakness, dizziness, shortness of breath and headaches (LSA, 1994). On the other hand, Feldman et al. (2006) reported that the normal range of hemoglobin values was 8 to $15 \mathrm{~g} / \mathrm{dL}$ in cattle. Therefore, the values of these measures in the current study were within the normal range, indicating no significant changes in such health related symptoms.

Plasma albumin showed low-, intermediate- and highlevel $(\mathrm{p}<0.05)$ for control, T1 and T2, whereas NEFA was high-, intermediate- and high-level $(\mathrm{p}<0.05)$ for control, T1 and T2, respectively (Table 4). The higher albumin concentration may be due to the improvements of ruminal microbial protein synthesis or by greater absorption of protein. Various substances such as amino acids adhere particularly to albumin in the blood, which plays a role in their transport (Rivera et al., 2005). However, it was not supported by the total protein concentration being the highest in T1 group though there was no significantly difference. Hart et al. (2008) reported that essential oils from medicinal plants apply their main effects on the rumen through reduction of protein and starch and the degradation of amino acids. The degradation depends on dose, chemical structure, and ration combinations of MPB. Therefore, further study is required to investigate the effect of MPB on rumen turnover rate and microbial protein synthesis.

Lower feed intake is associated with increased NEFA which contributes to the risk of fatty liver and negative energy balance (Allen et al., 2009). Decreasing concentrations of plasma insulin could allow the glucocorticoids to express a ketogenic effect resulting in the release of NEFA from adipose tissue through a negative energy balance (Mills and Jenny, 1979; Veenhuizen et al., 1991). On the other hand, NEFA concentration is increased by up-regulated lipolysis as a feature of metabolic disorder (Van Hoeck et al., 2011), suggesting that NEFA concentration was increased by cytotoxic effects on several cell types, such as Leydig cells, nerve growth factor differentiated cells and hepatocytes. The results of feed intake and corticoid concentration in the present study were not affect by the treatments (Tables 3 and 4), indicating that

Table 4. Substitution effect of a total mixed ration by medicinal plant by-products on blood corpuscles and plasma chemical composition in the late fattening period of Hanwoo steers

\begin{tabular}{|c|c|c|c|c|}
\hline \multirow{2}{*}{ Item } & \multicolumn{3}{|c|}{ Treatment $^{1}$} & \multirow{2}{*}{ SEM } \\
\hline & Control & Treatment 1 & Treatment 2 & \\
\hline No. of animals & 9 & 9 & 9 & \\
\hline \multicolumn{5}{|l|}{ Blood corpuscles } \\
\hline White blood cell $(\mathrm{K} / \mu \mathrm{L})$ & 7.29 & 8.50 & 12.65 & 14.6 \\
\hline Red blood cell $(\mathrm{M} / \mu \mathrm{L})$ & 7.00 & 7.19 & 7.89 & 0.47 \\
\hline Hemoglobin $(\mathrm{g} / \mathrm{dL})$ & $11.03^{\mathrm{y}}$ & $13.03^{\mathrm{x}}$ & $14.07^{\mathrm{x}}$ & 0.71 \\
\hline Hematocrit (mg/mL) & $292^{y}$ & $353^{\mathrm{x}}$ & $387^{x}$ & 21.7 \\
\hline Platelets $\left(10^{3} / \mathrm{mm}^{3}\right)$ & 339 & 325 & 311 & 62.9 \\
\hline \multicolumn{5}{|l|}{ Plasma chemical compositions } \\
\hline Total protein $(\mathrm{g} / \mathrm{dL})$ & 3.10 & 3.83 & 3.70 & 0.46 \\
\hline Albumin $(\mathrm{g} / \mathrm{dL})$ & $3.77^{\mathrm{y}}$ & $3.93^{\mathrm{x}, \mathrm{y}}$ & $4.10^{\mathrm{x}}$ & 0.16 \\
\hline Calcium (U/L) & 9.53 & 9.10 & 9.53 & 0.52 \\
\hline Phosphorus (mg/dL) & 8.00 & 7.57 & 7.40 & 1.26 \\
\hline Non-esterified fatty acid (ueq/L) & $0.18^{\mathrm{x}}$ & $0.11^{\mathrm{x}, \mathrm{y}}$ & $0.09^{\mathrm{y}}$ & 0.04 \\
\hline Blood urea nitrogen $(\mathrm{mg} / \mathrm{dL})$ & 12.33 & 15.00 & 13.33 & 2.43 \\
\hline Corticoid (ng/dL) & 3.99 & 1.96 & 3.17 & 2.26 \\
\hline
\end{tabular}

SEM, standard error of the means.

${ }^{1}$ Medicinal plant by-products supplied to total mixed ration: control, no supplement; treatment $1,30 \mathrm{~g} / \mathrm{kg}$; treatment 2, $50 \mathrm{~g} / \mathrm{kg}$.

${ }^{\mathrm{x}, \mathrm{y}}$ Values in the same row with different superscripts differ at $\mathrm{p}<0.05$. 
Table 5. Substitution effect of a total mixed ration by medicinal plant by-products on the carcass traits and meat grades in the late fattening period of Hanwoo steers

\begin{tabular}{|c|c|c|c|c|}
\hline \multirow{2}{*}{ Item $^{1}$} & \multicolumn{3}{|c|}{ Treatment $^{b}$} & \multirow{2}{*}{ SEM } \\
\hline & Control & Treatment 1 & Treatment 2 & \\
\hline No. of animals & 9 & 9 & 9 & \\
\hline \multicolumn{5}{|l|}{ Carcass trait } \\
\hline Carcass weight (kg) & 366 & 382 & 375 & 42.7 \\
\hline Carcass rate $(\mathrm{g} / \mathrm{kg})$ & 560 & 561 & 572 & 8.20 \\
\hline Backfat thickness (mm) & 11.0 & 14.3 & 7.00 & 6.11 \\
\hline Eye muscle area $\left(\mathrm{cm}^{2}\right)$ & 80.7 & 90.0 & 90.3 & 10.1 \\
\hline \multicolumn{5}{|l|}{ Meat grade } \\
\hline Yield grade & $2.00^{\mathrm{y}}$ & $2.11^{\mathrm{y}}$ & $1.00^{\mathrm{x}}$ & 0.26 \\
\hline Quality grade & $3.00^{\mathrm{x}}$ & $1.67^{\mathrm{y}}$ & $2.33^{\mathrm{x}, \mathrm{y}}$ & 0.27 \\
\hline
\end{tabular}

MPB supplementation in Hanwoo steers was not adverse to their health and energy balance.

\section{Carcass characteristics}

In the present study, carcass weight, carcass rate, backfat thickness and rib eye muscle area were not affected by MPB supplementation to TMR, whereas the meat grade was improved $(p<0.05$, Table 5). Yield grade was highest $(p<0.05)$ in the T2 group and quality grade was highest $(p<0.05)$ in the T1 group. Antioxidants prevent discoloration (Waylan et al., 2002; Zhong et al., 2009), therefore, the oxidative status of the feed given to animals has a significant influence on the final meat quality. For instance, antioxidant vitamin $\mathrm{E}$ in feed guarantees high $\alpha$-tocopherol deposition in meat, while feeding animals with oxidizing feed clearly results in lower $\alpha$-tocopherol contents in the meat (Lo Fiego et al., 2004). The $\alpha$-tocopheryl acetate supplemented in the feed does not function as an antioxidant until it is hydrolyzed in the small intestine into free $\alpha$-tocopherol. However, once liberated in the small intestine, $\alpha$-tocopherol regains its antioxidant activity. Free radicals, peroxides and other reactive oxygen species present in the feed will thus be neutralized by $\alpha$ - tocopherol leading to a reduction of the $\alpha$-tocopherol content to be deposited in the muscle (Lauridsen et al., 1994; Lauridsen et al., 1995; Dirinck et al., 1996; Tesoriere et al., 2002). Flavonoids and phenolic acids, the most persistent groups of plant phenolics, are widely present in medicinal plants. These compounds are effective against the deleterious effect of reactive oxygen species. Therefore, we speculate that MPB supplementation to diets may play significant role in meat quality as an antioxidant in feed. However, further detailed studies are needed to clarify the effect of MPB as an antioxidant in feed on meat quality for Hanwoo steers, which active substances will affect to improve meat quality.

\section{Economic efficacy}

Daily feed costs were decreased by $0.5 \%$ and $0.8 \%$ for $\mathrm{T} 1$ and T2 compared to control (Table 6). Consequently, carcass prices were increased by $18.1 \%$ and $7.6 \%$ for $\mathrm{T} 1$ and $\mathrm{T} 2$, respectively. Based on the results in the present study, it is suggesting that substitution of a TMR by a MPB may be more profitable to the late fattening period of Hanwoo steers. Again, further study is required to demonstrate the effect of substituting concentrate by a MPB in the late fattening of

Table 6. Substitution effect of a total mixed ration by medicinal plant by-products on the economic efficacy in the late fattening period of Hanwoo steers

\begin{tabular}{lccc}
\hline \multirow{2}{*}{ Item } & \multicolumn{3}{c}{ Treatment $^{1}$} \\
\cline { 2 - 4 } & Control & Treatment 1 & Treatment 2 \\
\hline Total feed cost (Won/180 d/head) & $1,054,440$ & $1,049,645$ & $1,046,448$ \\
Concentrate & 864,000 & 864,000 & 864,000 \\
Total mixed ration & 190,440 & 185,645 & 182,448 \\
Daily feed cost (Won/d/head) & $5,688.0$ & $5,661.4$ & $5,643.6$ \\
Index (\%) & 100.0 & 99.53 & 99.22 \\
Carcass price (Won/head) & $5,119,380$ & $6,044,608$ & $5,507,662$ \\
Index (\%) & 100.0 & 118.1 & 107.6 \\
\hline
\end{tabular}

\footnotetext{
${ }^{1}$ Medicinal plant by-products supplied to total mixed ration: control, no supplement; treatment $1,30 \mathrm{~g} / \mathrm{kg}$; treatment $2,50 \mathrm{~g} / \mathrm{kg}$.
} 
Hanwoo steers. Plant secondary metabolites contained in medicinal plants can modulate ruminal fermentation and improve nutrient utilization in ruminants (Hristov et al., 1999). Consequently, the supplementation of medicinal plants or their by-products containing antimicrobials, antioxidants and stimulants of immune system may alter rumen microbial activity and rumen fermentation of cattle fed a high-concentrate diet. Therefore, appropriate use of MPB as feed additives may influence production efficiency as well as being an alternative to synthetic compounds (i.e., antibiotic) in the late fattening period of Hanwoo steers.

\section{CONCLUSION}

Although medicinal plants and their by-products have enormous potential to be developed as a possible alternative to antibiotics and enhancers of production efficiency, indigenous medicinal plants and its by-products have not been seriously considered as a dietary supplement for Hanwoo steers. Therefore, this study attempted to evaluate the potential use of MPB as a feed additive and the results suggest that the substituting TMR with $30 \mathrm{~g} / \mathrm{kg}$ MPB may have potential as a feed supplement during in the late fattening period of Hanwoo steers to improve feed efficiency, meat quality and possibly carcass price. However, further study is required to better understand the extent to which MPB supplementation to TMR affected ruminal metabolites before recommending their use as dietary supplements.

\section{CONFLICT OF INTEREST}

We certify that there is no conflict of interest with any financial organization regarding the material discussed in the manuscript.

\section{ACKNOWLEDGMENTS}

This work was carried out with the support of "Cooperative Research Program for Agriculture Science \& Technology Development (Project No. PJ011060)" Rural Development Administration, Republic of Korea. We would like to thank Agricultural Union Corporation, San-cheong, Korea for their kind help with the feeding trial. This work was presented as a part of a doctoral dissertation by SeungKyu-Ahn.

\section{REFERENCES}

Aboul-Fotouh, G. E., S. M. Allam, E. I. Shehata, and S. N. A. EIAzeem. 2000. Effect of some medicinal plants as feed additives on milk production and composition of lactating buffaloes. Egypt. J. Nutr. Feed. 3:31-41.

Ahmed, A. A., Neamat I. Bassuony, Set El-Habiab S. Awad, A. M.
Aiad, and S. A. Mohamed. 2009. Adding natural juice of vegetables and fruitage to ruminant diets (b) nutrients utilization, microbial safety and immunity, effect of diets suplemented with lemon, onion and garlic juice fed to growing buffalo calves. World J. Agric. Sci. 5:456-465.

Allen, M. S., B. J. Bradford, and M. Oba. 2009. Board invited review: The hepatic oxidation theory of the control of feed intake and its application to ruminants. J. Anim. Sci. 87:33173334.

AOAC. 2005. Official methods of analysis. 16th edn. AOAC International, Washington, DC, USA.

Choi, J. H., D. W. Kim, Y. S. Moon, and D. S. Chang. 1996. Feeding effect of oriental medicine on the functional properties of pig meat. J. Korean Soc. Food Nutr. 25:110-117.

Dirinck, P., A. De Winne, M. Casteels, and M. Frigg. 1996. Studies on vitamin $\mathrm{E}$ and meat quality: 1. Effect of feeding high vitamin E levels on time-related pork quality. J. Agric. Food Chem. 44:65-68.

Disler, P. B., S. R. Lynch, R. W. Charlton, J. D. Torrance, T. H. Bothwell, R. B. Walker, and F. Mayet. 1975. The effect of tea on iron absorption. Gut 16:193-200.

Elvin-Lewis, M. 2001. Should we be concerned about herbal remedies. J. Ethnopharmacol. 75:141-164.

Feldman, B. R., J. G. Zinkl, and N. C. Jain. 2006. Schalm's veterinary hematology. Blackwell Publishing Professional, Ames, IA, USA.

Goto, T., Y. Yoshida, M. Kiso, and H. Nagashima. 1996. Simultaneous analysis of individual catechins and caffeine in green tea. J. Chromatogr. A 749:295-299.

Hadiya, K., S. Maini, D. S. Rekhe, and K. Ravikanth. 2009. Accelerated growth programme with polyherbal formulations for dairy calves. Vet. World 2:62-64.

Hart, K. J., D. R. Yáñez-Ruiz, S. M. Duval, N. R. McEwan, and C. J. Newbold. 2008. Plant extracts to manipulate rumen fermentation. Anim. Feed Sci. Technol. 147:8-35.

Hristov, A. N., T. A. McAllister, F. H. Van Herk, K. J. Cheng, C. J. Newbold, and P. R. Cheeke. 1999. Effect of yucca schidigera on ruminal fermentation and nutrient digestion in heifers. J. Anim. Sci. 77:2554-2563.

Kim, S. U., J. Y. Jung, S. G. Park, and S. S. Jo. 2008. Effects of feeding medicinal herbs on growth performance and carcass quality in finishing pigs. Korean J. Vet. Serv. 31:555-566.

Lauridsen, C., K. Jakobsen, and T. K. Hansen. 1995. The influence of dietary ethoxyquin on the vitamin E status in broilers. Arch. Tierernahr. 47:245-254.

Lauridsen, C., K. Jakobsen, and J. F. Jensen. 1994. Comparative studies on the effect of butylhydroxytoluene and ethoxyquin on the antioxidative and oxidative balance in broilers. J. Anim. Physiol. Anim. Nutr. 72:26-37.

Lee, S. J., N. H. Shin, J. J. An, G. M. Chu, Y. H. Moon, and S. S. Lee. 2006. Effects of replacing rice straw with by-products of medical herbs on the in vitro fermentation characteristics. J. Agric. Life Sci. 45:69-79.

Lo Fiego, D. P., P. Santoro, P. Macchioni, D. Mazzoni, F. Piattoni, F. Tassone, and E. De Leonibus. 2004. The effect of dietary supplementation of vitamins $\mathrm{C}$ and $\mathrm{E}$ on the $\alpha$-tocopherol content of muscles, liver and kidney, on the stability of lipids, and on certain meat quality parameters of the longissimus dorsi of rabbits. Meat Sci. 67:319-327. 
LSA, Leukemia Society of America. 1994. Blood functions and compositions. Neutropenia Support Association Inc. New York, NY, USA.

Mills, S. E. and B. F. Jenny. 1979. Effects of high concentrate feeding and fasting on plasma glucocorticoids in dairy heifers. J. Anim. Sci. 48:961-965.

Ndlovu, T., M. Chimonyo, A. I. Okoh, V. Muchenje, K. Dzama, S. Dube, and J. G. Raats. 2009. A comparison of nutritionallyrelated blood metabolites among nguni, bonsmara and angus steers raised on sweetveld. Vet. J. 179:273-281.

Park, J. H. and Y. H. Song. 1997. Nutritive values of Korean medical herb residue as dietary supplements for broiler chicks. Korean J. Anim. Nutr. Feed. 21:59-64.

Park, S. J. and S. O. Yoo. 1999. Effects of supplemention of Chinese medicine refuse on performance and physiology in broiler chicks. Korean J. Poult. Sci. 26:195-201.

Rivera, J. D., S. E. Bachman, M. E. Hubbert, M. E. Branine, R. L. Horst, S. N. Williams, and M. L. Galyean. 2005. Short communication: serum and tissue concentrations of vitamin D metabolites in beef heifers after buccal dosing of 25hydroxyvitamin D3. J. Dairy Sci. 88:1364-1369.

Tesoriere, L., D. D'Arpa, D. Butera, A. M. Pintaudi, M. Allegra, and M. A. Livrea. 2002. Exposure to malondialdehyde induces an early redox unbalance preceding membrane toxicity in human erythrocytes. Free Radic. Res. 36:89-97.
Van Hoeck, V., R. G. Sturmey, P. Bermejo-Alvarez, D. Rizos, A. Gutierrez-Adan, H. J. Leese, P. E. J. Bols, and J. L. M. R. Leroy. 2011. Elevated non-esterified fatty acid concentrations during bovine oocyte maturation compromise early embryo physiology. Plos One 6:e23183.

Vandergrift, B. 1998. Equine applications for herbal products. In: Biotechnology in the feed industry: proceedings of alltech's fourteenth annual symposium (Eds. T. P. Lyons and K. A. Jacques). Nottingham University Press, Nottingham, UK. pp. 293-300.

Veenhuizen, J. J., J. K. Drackley, M. J. Richard, T. P. Sanderson, L. D. Miller, and J. W. Young. 1991. Metabolic changes in blood and liver during development and early treatment of experimental fatty liver and ketosis in cows. J. Dairy Sci. 74:4238-4253.

Waylan, A. T., P. R. O'Quinn, J. A. Unruh, J. L. Nelssen, R. D. Goodband, J. C. Woodworth, M. D. Tokach, and S. I. Koo. 2002. Effects of modified tall oil and vitamin $\mathrm{E}$ on growth performance, carcass characteristics, and meat quality of growing-finishing pigs. J. Anim. Sci. 80:1575-1585.

Zhong, R. Z., C. Y. Tan, X. F. Han, S. X. Tang, Z. L. Tan, and B. Zeng. 2009. Effect of dietary tea catechins supplementation in goats on the quality of meat kept under refrigeration. Small Rumin. Res. 87:122-125. 